\title{
The New Brunswick Tree Improvement Council is 20 years old
}

\author{
by Dale Simpson ${ }^{1}$ and Kathleen Tosh $^{2}$
}

Applied breeding programs in New Brunswick have been coordinated for the past 20 years by the New Brunswick Tree Improvement Council. First-generation programs for black spruce (Picea mariana [Mill.] BSP) and jack pine (Pinus banksiana Lamb.) consisted of seedling seed orchards and openpollinated family tests, in contrast to those of white spruce (Picea glauca [Moench] Voss) and tamarack (Larix laricina [Du Roi] K.Koch), which were clonal seed orchards and controlpollinated progeny tests. Production from the seed orchards has been regular and heavy. In only 15 years, most reforestation stock was being grown from orchard seed. Early results from black spruce and jack pine realized gain tests indicate increases of 12 to $20 \%$ in volume growth by using genetically improved seed. This is double the prediction that was made when the program started. Stem straightness of jack pine trees has been improved by $25 \%$. Second-generation programs of black spruce and jack pine are well underway and production from these orchards is steadily increasing. Indications are that gains from using this seed will be substantial. An ongoing research and development program has contributed to a more effective breeding program, has increased seed production, and has given further insights into wood quality. The success of the Council's program is due to excellent participation and team work by government, university and industrial agencies and their long-term commitment.

Key words: seed production, tree improvement, black spruce, white spruce, jack pine, tamarack

\section{Introduction}

The New Brunswick Tree Improvement Council (NBTIC) was established in 1976 to coordinate tree improvement efforts of government and industrial agencies and to facilitate the free exchange of genetic material and information. At the time, reforestation programs were expanding rapidly and all agencies recognized the impact tree improvement could have on wood supply. The Council was modeled after the successful North Carolina State University - Industry Cooperative Tree Improvement Program with one notable exception: there are no membership fees. Direction and management was provided by the Canadian Forest Service. The provincial government is a core member, participating in all aspects of the program. A number of industrial members, operating primarily on Crown land, were reluctant initially to participate. Following enactment of the Crown Lands and Forests Act in 1981, when management of Crown land was granted to the forest companies, they became involved in the Council's program. Since the Council's formation 20 years ago, significant

\footnotetext{
${ }^{1}$ Canadian Forest Service - Atlantic Forestry Centre, P.O. Box 4000, Fredericton, New Brunswick, Canada E3B 5P7.

${ }^{2}$ Department of Natural Resources and Energy, Kingsclear Provincial Forest Nursery, 3732 Route 2 Highway, Island View, New Brunswick, Canada E3E 1G3.
}

Les programmes d'amélioration génétique appliqués du Nouveau-Brunswick ont été coordonnés au cours des dernières 20 années par le Conseil d'amélioration génétique du NouveauBrunswick. Les programmes de la première génération portant sur l'épinette noire (Picea mariana [Mill.] BSP) et le pin gris (Pinus banksiana Lamb.) étaient constitués de vergers à graines et de tests de descendance à partir de pollinisation libre, alors que les programmes sur l'épinette blanche (Picea glauca [Moench] Voss) et le mélèze (Larix laricina [Du Roi] K. Koch), portaient sur des vergers à graines issus de clones et sur des tests de descendance à partir de pollinisation contrôlée. La production des vergers à graines a été régulière et abondante. En seulement 15 ans, la majeure partie des stocks de reboisement a été produite à partir de vergers à graines. Les résultats préliminaires de gain tirés de l'épinette noire et du pin gris indiquaient une augmentation en volume de 12 à $20 \%$ suite à l'utilisation de semences génétiquement améliorées. Il s'agit d'une prévision deux fois plus importante qu'au début du programme. La droiture de la tige chez le pin gris a été améliorée de $25 \%$. Les programmes de la deuxième génération pour l'épinette noire et le pin gris sont bien établis et la production issue de ces vergers augmente sans cesse. Il semble selon les premiers résultats que les gains tirés de ses semences seront substantiels. Le maintien de la recherche et du programme de développement a permis de générer un programme d'amélioration génétique plus efficace, d'augmenter la production de semences, et d'entrevoir des bénéfices futurs en terme de qualité du bois. Le succès du programme du Conseil provient de l'excellente participation et du travail d'équipe entre les organismes gouvernementaux, universitaires et industriels ainsi que leur engagement à long terme.

Mots clés: production de semences, amélioration génétique, épinette noire, épinette blanche, pin gris, mélèze laricin

progress has been made. The Council's initial two objectives were to provide an adequate supply of seed from locally adapted sources and to provide genetically improved seed to meet the reforestation demands. Both of these goals have been realized.

At present, the Council comprises eight industrial companies, two universities, and provincial and federal governments. The provincial government manages seed orchards and produces all seedlings for planting on Crown land. Several industrial companies also produce seed and seedlings for their freehold reforestation programs. The provincial government is the lead agency for coordinating and conducting breeding programs and growing seedlings for genetic testing. Industrial members participate in selection and breeding and are responsible for planting, managing, and measuring the tests.

All first-generation seedling seed orchards from which cones are collected have been rogued twice, whereas roguing is just beginning in clonal orchards. Seed requirements for the annual production of 30 million seedlings for provincial reforestation programs are being met from orchard production. A second-generation program is well underway and seed orchards are already producing significant quantities of seed. This paper will outline the progress NBTIC has accomplished to date and the future direction of the Council. 


\section{Stand Tests}

To meet the initial objective of providing an adequate supply of seed from known local sources, the Council concentrated on black spruce (Picea mariana [Mill.] BSP) and jack pine (Pinus banksiana Lamb.). These species were most widely planted because of their ease of nursery production and adaptability to a broad range of sites. Phenotypically superior stands were selected and seed collected. The seed was grown and seedlings planted in replicated tests in order to identify stands that were the best seed sources for particular areas of the province. Once the best stands were identified, they served as an interim supply of seed until production from seed orchards was sufficient. These tests were also useful for identifying average performing sources to serve as checklots in realized gain tests and progeny tests.

\section{Plus Tree Selection}

The four tree species chosen for genetic improvement were black spruce, jack pine, white spruce (Picea glauca [Moench] Voss), and tamarack (Larix laricina [Du Roi] K.Koch). Black spruce and jack pine were chosen by the Council because of their importance as reforestation species for pulp and paper. White spruce was chosen because of its importance in the sawmill industry, as well as for pulp and paper. Tamarack was selected for improvement because the Council felt that with its rapid growth, this species could be important for reducing the impact of a predicted wood supply shortage.

Two different breeding strategies were adopted based on species biology and genetic information known at the time. For black spruce and jack pine, the seedling seed orchard-family testing strategy was adopted. This was implemented by extensively selecting a large number of phenotypically superior trees and establishing open-pollinated family tests and seedling seed orchards. The comparison tree method was used with an emphasis on height growth for black spruce and, in addition, stem straightness and crown form for jack pine. Once a candidate tree was located, five dominant trees were identified within 50 to $200 \mathrm{~m}$. Height, diameter at breast height, age at breast height, and height to the first live whorl of branches were measured for the candidate tree and five comparison trees. The candidate tree was then rated and scored against the comparison trees for height and quality traits. For candidate jack pine, trees to be graded as plus trees had to score points for two out of three major quality traits, namely height, straightness, and crown. Black spruce candidate trees were not scored, but had to be superior or at least average for eight out of nine traits, namely straightness, stem taper, crown radius and density, branch angle and size, pruning ability, cone production, and freedom from insect and disease (Simpson 1992). In total, 1233 black spruce and 845 jack pine trees were selected.

A strategy employing clonal seed orchards and control-pollinated progeny tests was adopted for white spruce and tamarack. Criteria for plus tree selection were more rigorous. The comparison-tree selection method was used, with strong emphasis placed on height growth, straightness, and crown form. Trees were grafted for establishment of seed orchards and clone banks. A total of 414 white spruce and 268 tamarack plus trees was selected. The plus tree selection phase of the program was completed in 1987.

The breeding populations of all four species were supplemented with material from Prince Edward Island, Nova
Scotia, and the State of Maine. This provided an opportunity to evaluate the suitability of genetic material from adjacent jurisdictions for inclusion into the Council's program.

\section{Seed Orchards}

Black spruce and jack pine seedling seed orchards were established from 1978 to 1986 , with a total of 80 ha of black spruce and 43 ha of jack pine. These orchards were established using a single-tree plot design with a planting spacing of $1 \times$ $2 \mathrm{~m}$. Initial planting density was very high to allow for intensive roguing. Most of the seedling seed orchards were established on average or above average sites that were clearcut and had the slash crushed, removed, or burned. On average, at least 100 families or 13000 seedlings were planted at a time in each orchard. Seedlings were randomly planted within each row and mapped immediately after planting. The orchards received herbicide or were cleaned as necessary to maintain a competitionfree growing environment. Fertilizer was generally not applied to promote tree growth.

White spruce and tamarack clonal seed orchard establishment was not completed until 1990. A total of 41 ha of white spruce and 23 ha of tamarack clonal seed orchard was set up by Council members. Orchards were established on intensively prepared sites, either former agricultural land or forested sites converted to fields. Following site preparation, a permanent sod cover crop was planted. Clone placement was determined by a computer algorithm based on the permutated neighborhood design concept using a computer program, COOL (Bell and Fletcher 1978). This created a randomized layout and maximized the distance between ramets of the same clone. Planting spacing ranged from $2 \times 5 \mathrm{~m}$ to $3 \times 6 \mathrm{~m}$. Blocks of clones, usually 50 per block, were planted over several years. The orchards are intensively managed for seed production, with fertilizer application to promote tree health and vigor and, in some cases, regular application of gibberellin to promote cone production. Damaging insects are monitored and, when necessary, appropriate control measures are taken.

\section{Seed Orchard Production}

Seed production from orchards has been far greater than the Council anticipated. At the time of first-generation orchard establishment, good information on seed production was minimal (McPherson et al. 1982) and a significant portion of seedling production was bareroot stock with low seed use efficiency. This led to very conservative estimates of seed production and overestimates of seed orchard area requirements. Jack pine started to produce seed in 1984, followed by black spruce in 1987 (Fig. 1). The jack pine orchards have produced steady cone crops since 1988. Orchards have tended to produce annual cone crops with some year-to-year fluctuations.

Cone harvests fluctuate according to crop size and seed demand. As cone production increased and there was more seed in storage, cones were not collected from all orchards. Many of the NBTIC agencies have sufficient orchard seed in storage and are either not collecting from their first-generation seed orchards or concentrating collection in the most heavily rogued orchards. All producing black spruce and jack pine orchards have been rogued once and many have been rogued a second time. The impact of roguing on seed production has generally been minimal. The first roguing for black spruce orchards is based on 10-year height data and the second 


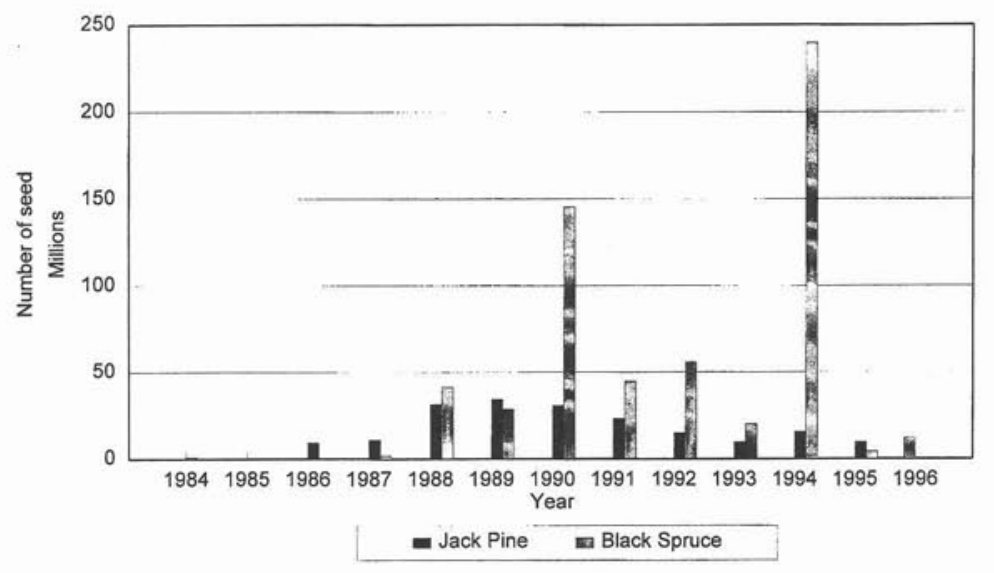

Fig. 1. Annual quantity of seed collected from black spruce and jack pine seedling seed orchards. roguing is primarily based on 15 -year volume data from family tests. Jack pine seedling seed orchards were first rogued based on seven-year height and stem straightness while a second roguing was based on 12-year volume. For both species, the poorest $50 \%$ or more of the families were removed from the orchards at each roguing. A phenotypic roguing was also conducted among remaining trees to ensure orchard trees are competition-free.

White spruce clonal seed orchards started producing seed in 1988; but, it was not until 1991 that any significant amount was produced (Fig. 2). Tamarack seed production started in 1991, with a good cone crop produced in 1994 (Fig. 2). Several agencies have started to rogue their clonal orchards based on information from 5-year-old progeny tests. This is being done conservatively, with the removal of the poorest $10-15 \%$ of the clones. Roguing will become more intensive as older progeny test data become available.

\section{Genetic Testing}

Planting of family and progeny tests is a major part of the Council's program. The first major out planting occurred in 1978 (Coles 1979). During the 20 -year period, 235 tests were planted on 274 ha. These tests provide data for several purposes, including roguing orchards, quantifying gain in various traits, and identifying superior trees for next generation improvement. Family tests of black spruce and jack pine were established at the same time as the seed orchards on cutovers on four or five sites. The layout was four-tree row plots randomly planted in each of 10 replications at a spacing of $2 \times 2 \mathrm{~m}$. Measurement schedules were developed to coincide with the timing of seed orchard roguing.

Cones were not collected from white spruce and tamarack plus trees. The genetic quality of these selections is determined by conducting controlled pollinations on the ramets and outplanting the resulting seedlings into progeny tests. A complementary mating design was instituted consisting of polycrossing and pair-mating. Polycross tests are used to determine the breeding value of plus trees and involves pollination of seed cones of each selection with a uniform mixture of pollen. Tests are planted on cut-over sites at four or five locations. Based on experience with family testing, fewer individuals per family are tested and the size of the progeny tests is kept to a maximum of 1 ha to minimize environmental effects. A typical layout consists of two-tree row plots randomly planted in each of 15 replications using a planting spacing of $2 \times 2 \mathrm{~m}$. Almost $90 \%$ of the white spruce and $80 \%$ of the tamarack plus trees have been tested. Pair-mating is conducted randomly among the clones such that each clone is mated twice. Seedlings are planted in selection tests as non-replicated 48-tree blocks at two sites. Superior families will be identified based on progeny test data and individual trees selected in the selection tests based on field assessment.

\section{Second Generation}

Selection of trees for second-generation breeding populations, which was started in 1989 , is based on 10 -year family test data for black spruce and seven-year data for jack pine. Top performing black spruce families were identified based on height growth, while for jack pine, stem straightness and height were used. Six candidate trees were identified based on height growth, phenotypically graded in the family tests for straightness and crown and branching characteristics, and the final selection made from each family based on a combination of superior phenotypic and metric traits. The goal was to form breeding populations containing 400 trees of each species. Jack pine selection was completed in 1994 while black spruce will be completed in 1997.

Selected trees are propagated by grafting. Scions are collected during the winter and grafted using the top-cleft method. Several ramets of each clone are planted in clone banks for preservation and future breeding. Seed orchards were established using clones from the top-ranking 40 families from the three oldest series of family tests. These orchards are intensively managed to promote rapid growth and early cone production. Seed production, which began in 1992, has shown a steady increase (Fig. 3).

Breeding of second-generation selections began in 1990. As for white spruce, a complementary mating design is being conducted. A polycross, using a mix of twenty pollens unrelated to the selected trees, is used to estimate breeding values for the selected trees. Polycrossing of black spruce and jack pine has, for the most part, taken place in situ in the family tests. This enabled progeny tests to be established three to four years sooner than would be possible with accelerated growth and breeding techniques. This will allow genetic roguing to be conducted much sooner than is usually possible in clonal orchards which in turn will substantially increase genetic gain. Breeding of black spruce has continued to be successful and can generally be com- 
pleted with one attempt. Field breeding of jack pine was done the first four years but has since been conducted in the clone banks. Over $65 \%$ of black spruce and jack pine selections have been polycrossed. This rapid progress was possible due to excellent cooperation from all members assisting with the in situ breeding and regular cone crops.

Progeny tests are necessary to provide data to rogue the seed orchards. They are planted on cut-over sites as well as in the nursery or greenhouse. Field tests are planted using the same design as previously described for white spruce and tamarack. A test is also planted in the nursery for each series of black spruce progeny tests. Based on three-year height data from these nursery tests, the parental clones are ranked and uniformly assigned to 20 -tree breeding groups (sublines). For jack pine, a greenhouse progeny test is used where the seedlings are subjected to two accelerated growth cycles (six months per cycle) followed by height measurements. Following data analysis, clones are assigned to breeding groups in the same manner as for black spruce. Breeding is conducted assortatively within each breeding group to generate up to 24 full-sib families per group (see Park et al. 1993). The resulting progeny will be planted in replicated full-sib progeny tests and be a source of material for the third generation. The first polycross tests of black spruce were planted in 1991 while those for jack pine were planted in 1993. Each series of tests contains two unimproved checklots representing average performing stands, as determined from data collected from the stand tests that were first established by the Council. Good progress has been made with testing. Over $50 \%$ of the black spruce and $60 \%$ of the jack pine selections are now progeny tested. Five-year data were collected from the two older series of black spruce tests, enabling roguing to be conducted in seed orchards.

Breeding has commenced in the sublines for each species to generate full-sib progeny. All work is being conducted in the clone banks. The production of sufficient pollen has been a problem with the black spruce ramets. This necessitated collecting pollen from the ortets and storing it. Nonetheless, good progress was achieved with $20 \%$ of the total number of crosses completed. Mating among jack pine clones is progressing well with about $20 \%$ of the crosses completed.

\section{Gains}

All tree improvement programs are established with the premise that there will be an improvement in the trait(s) being selected. The most common selection trait is volume growth. At the time the Council's program was initiated, an increase of $10 \%$ in volume production was generally accepted as being reasonable to achieve. Certainly as family test data were analyzed, estimates of gain could be determined by comparing growth of better families with that of unimproved stand checklots, and genetic parameters are calculated to provide estimates of gain. It was not until seedling seed orchards began to produce seed and were being rogued that tests could be established to quantify gains achieved from the black spruce and jack pine programs.

A series of realized gain tests was established for each species in 1991. Test design consisted of six seedlots planted in four replicates using 64-tree plots and planted at five locations. Seedlots consisted of rogued and unrogued orchard and unimproved stand checklots. These tests were measured when five years old. The unrogued black spruce orchard seedlot was the same height as the average checklot; but, the rogued orchard seedlot was

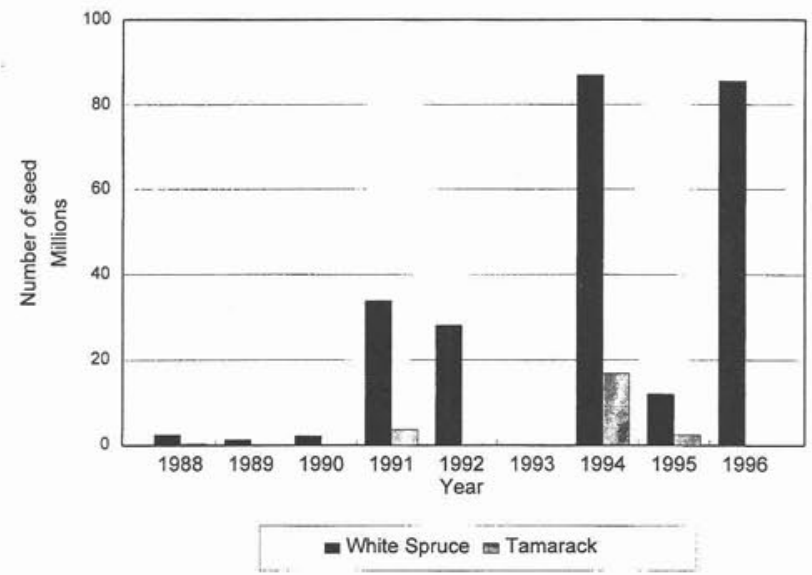

Fig. 2. Annual quantity of seed collected from white spruce and tamarack clonal seed orchards.

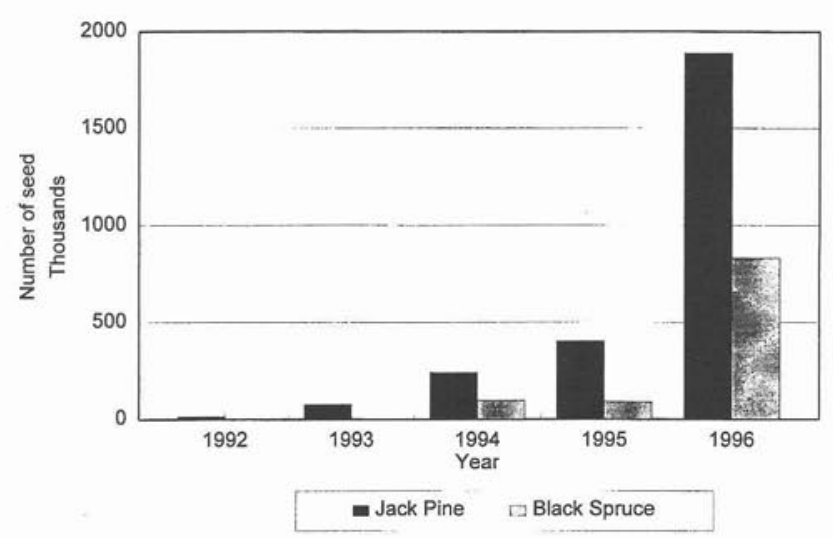

Fig. 3. Annual quantity of seed collected from second-generation black spruce and jack pine clonal seed orchards.

over $6 \%$ taller which can translate into a potential volume gain of 18 to $20 \%$. For jack pine, the unrogued seed orchard seedlot was 3\% taller than the checklots, while the seedlot from the same orchard following a second roguing was over $4 \%$ taller. This has the potential for a 12 to $15 \%$ gain in volume. Stem straightness is an important quality trait for improvement in jack pine. Selection is made for this trait when seed orchards are rogued. The seedlot from the seed orchard rogued twice was $25 \%$ straighter than the checklots. Significant areas of jack pine plantations from seed orchards have been established since 1988 and trees in these are straighter with narrower crowns than those in unimproved plantations. Although these are early results, they certainly demonstrate the potential for increases in wood volume and improvement of stem straightness. These gains can be applied to any wood supply analysis and will have an immediate impact on annual allowable cut.

\section{Data Analysis}

Establishment of tests is a necessary part of all tree improvement programs, and NBTIC members have planted a significant number. Tests serve many purposes, depending on their design and the type of material planted. Data collected are used to rogue seed orchards, identify candidate trees for selection, and quantify genetic parameters and gains in growth. The quan- 
tity of data quickly increases as more tests are measured and measurement of tests of different ages coincide. The Council recognized the need and importance of having a full-time data analyst. This position has been funded by the membership since 1990.

The analyst is responsible for analyzing data and summarizing the results. Seed orchard roguing prescriptions are produced and lists of candidate second-generation selections are generated. Data are analyzed on a PC platform using SAS software. Best Linear Prediction (BLP) has been incorporated into the data analysis procedures over the past several years. In addition to operational data analysis, the analyst performs an equally important function of more comprehensive analyses of data to provide advice for continued development and refinement of the Council's program.

\section{Research}

A tree improvement program benefits from research that provides insight, guidance, and solutions to problems and questions that arise. The Council has conducted projects independently as well as cooperatively with external agencies such as universities and the Canadian Forest Service.

Considerable effort was devoted by J.D. Irving, Limited to developing protocols for accelerated growth and reproductive bud initiation protocols for white and black spruce. This resulted in up to four years being saved in the breeding portion of the program (Greenwood et al. 1988). In conjunction with this, early testing of black spruce and jack pine was investigated to evaluate its feasibility to allow for early, low intensity seed orchard roguing and ranking of clones prior to specific crosses being conducted (Carter et al. 1990; Mullin et al. 1995).

Seed orchard management research focused primarily on promoting cone production. For black spruce, prescriptions were developed for applying varying quantities of ammonium nitrate fertilizer depending on tree size (Smith 1993a). Another aspect investigated was crown management of black and white spruce. Recommendations were developed regarding leader pruning, how much of the crown to remove, and the time of year and tree height at which these procedures should be performed (Smith 1993b). Large areas of first-generation seed orchards were planted, primarily due to insufficient data on cone and seed production. As these orchards matured, seed production increased rapidly beyond previous estimates and techniques to promote cone production were increasingly effective. To provide for more efficient orchard management, the meadow orchard, a new concept in seed orchards developed in New Zealand, was adapted for evaluation. Jack pine was chosen for this evaluation using second-generation clones. Accelerated growth techniques were used to grow the grafts to a larger size before field planting (Tosh 1994). The grafts are now at a size when crown management techniques can be applied, and with cone production starting, supplemental mass pollination will be used to maximize seed set and genetic gain.

Another area where considerable work has been conducted is wood quality. Increment cores and disks were collected from plus trees at the time of selection. The purpose of this was to obtain baseline data on wood density of these species in the province and to evaluate parent progeny relations in future. Wood density of plus trees tended to be higher than comparison trees and average values obtained from industry sampling from wood yards (Simpson 1992). The Pilodyn was evaluat- ed as a means for rapid, indirect evaluation of wood density for black spruce and jack pine and found to give reliable estimates for young jack pine (Villeneuve et al. 1987). Further evaluation of older black spruce (Zhang and Morgenstern 1995) and jack pine (Zhang and Chui 1996) family tests was conducted and concluded that selection for dry fiber weight maximized gains for both wood density and volume growth.

\section{The Future}

The NBTIC program has enjoyed a successful and productive 20 years. A continued strong commitment and cooperation among the membership will ensure constant growth for the program and continue the development of an excellent genetic resource for New Brunswick. Management of the program recently underwent reorganization as a result of the Canadian Forest Service withdrawing from active participation. The New Brunswick Department of Natural Resources and Energy now manages and directs the program. A research and development committee, composed of representatives from the provincial and federal governments, industry, and university, was formed to provide guidance for the program.

Second-generation breeding programs are well underway for black spruce and jack pine and will commence for white spruce within 5 to 10 years. Although the total number of seedlings planted is significantly less than when the Council's program began ( 30 million vs 60 million), this situation is likely to change as seed of increasing genetic quality is produced and forest management strategies evolve. Selection will continue to favor height and volume growth and stem straightness. Wood density is also a highly inherited trait that will be incorporated into the selection process.

Work has begun on evaluating clonal reforestation, and although this will always be a small component of the overall reforestation effort, it will be profitable when using intensively selected and bred material and planting on the most productive sites. It also provides flexibility in developing and deploying clones selected for changing product goals or environments. Also, genetic diversity of clonal plantations can be pre-determined by mixing known genotypes (Park et al., in press). Somatic embryogenesis is being actively pursued with black spruce (Adams et al. 1994).

Breeding strategies will continue to be modified as new theories are developed and insights are obtained from data collected from tests. Sublining will continue to be used as a means of compartmentalizing breeding populations and maintaining control over inbreeding. The mating design used within sublines may require refinement. Computer simulations indicate that although assortative mating results in a higher genetic gain over non-assortative mating, it also increases inbreeding more rapidly (Park et al., in press). This is an important trade-off that will require attention.

\section{Acknowledgments}

The authors appreciate the helpful comments provided by Greg Adams, Ronald Hallett, Yill Sung Park and Ronald Smith on an earlier draft of this paper.

\section{References}

Adams, G.W., M.G. Doiron, Y.S. Park, J.M. Bonga and P.J. Charest. 1994. Commercial potential of somatic embryogenesis in black spruce tree improvement. For Chron. 70: 593-598.

Bell, G.D. and A.M. Fletcher. 1978. Computer organised orchard 
layouts (COOL) based on the permutated neighbourhood design concept. Silvae Genet. 27: 223-225.

Carter, K.K., G.W. Adams, M.S. Greenwood and P. Nitschke. 1990. Early selection in jack pine. Can. J. For. Res. 20: 285-291.

Coles, J.F. 1979. New Brunswick Tree Improvement Council makes impressive strides. For. Chron. 55: 32-33.

Greenwood, M.S., G.W. Adams and M. Gillespie. 1988. Shortening the breeding cycle of some northeastern conifers. pp. 43-52 In Proc. 21 st Meet. Can. Tree Imp. Assoc., Part 2, E.K. Morgenstern and T.J.B. Boyle, Eds., Can. For. Serv., Petawawa Nat. For. Inst., ON. McPherson, J.A., E.K. Morgenstern and B.S.P. Wang. 1982. Seed production in grafted clonal orchards at Longlac, Ontario. For. Chron. 58: 31-34.

Mullin, T.J., G.W. Adams, J.D. Simpson, K.J. Tosh and M.S. Greenwood. 1995. Genetic parameters and correlations in tests of open-pollinated black spruce families in field and retrospective nursery test environments. Can. J. For. Res. 25: 270-285.

Park, Y.S., J.D. Simpson, G.W. Adams, E.K. Morgenstern and T.J. Mullin. 1993. An updated breeding strategy for black spruce (Picea mariana (Mill.) B.S.P.) in New Brunswick. pp. 41-54 In Breeding strategies of important tree species in Canada. Can. For. ServiceMaritimes, Information Rep. M-X-186E.

Park, Y.S., G.W. Adams and T.J. Mullin. 1997. Incorporation of new information and technology in breeding and deployment strategies for black spruce in the Maritimes, Canada. In Tree Improvement: Applied Research and Technology Transfer, S. Puri, ed. Oxford \& IBH Co. (in press).
Simpson, J.D. 1992. Plus tree selection in New Brunswick. Gov't Can., Can. For. Serv., N.B. Tree Imp. Council, Tech. Rep. No. 5, 19 p. Smith, R. 1993a. Operational cone induction in black spruce seedling seed orchards: what do we know after five years? pp. 128-135 In Proc. 23th Meet. Can. Tree Imp. Assoc., Part 2, J. Lavereau, ed., Can. For. Serv., Petawawa Nat. For. Inst., ON.

Smith, R. 1993b. Update on cooperative crown management studies in Maritime seed orchards. p. 23 In Proc. Fifth Annual Maritime Seed Orchard Managers' Workshop. R.F. Smith and L.D. Yeates, Compilers. Nat. Res. Can., Can. For. Serv.-Marit. Reg.

Tosh, K. 1994. Jack pine miniaturized orchard. p. 16 In Proc. Sixth Annual Maritime Seed Orchard Managers' Workshop. R.F. Smith and L.D. Yeates, Compilers. Nat. Res. Can., Can. For. Serv.-Marit. Reg.

Villeneuve, M., E.K. Morgenstern and L.P. Sebastian. 1987. Estimation of wood density in family tests of jack pine and black spruce using the Pilodyn tester. Can. J. For. Res. 17: 1147-1149.

Zhang, S.Y. and Y.H. Chui. 1996. Selecting dry fiber weight for higher and better quality jack pine fiber production. Wood Quality Imp. (in press).

Zhang, S.Y. and E.K. Morgenstern. 1995. Genetic variation and inheritance of wood density in black spruce (Picea mariana) and its relationship with growth: implications for tree breeding. Wood Sci. Tech. 30: 63-75. 